\title{
Detection and molecular characterization of group A rotavirus from hospitalized children in Rio de Janeiro, Brazil, 2004
}

\author{
Filipe Anibal Carvalho-Costa, Rosane Maria Assis, Alexandre Madi Fialho, \\ Márcio Neves Bóia*, Daniele Pires Dias Alves***, \\ Carolina Maria Miranda de Assis Martins**, José Paulo Gagliardi Leite/ ${ }^{+}$
}

\begin{abstract}
Laboratório de Virologia Comparada, Departamento de Virologia *Laboratório de Doenças Parasitárias, Departamento de Medicina Tropical, Instituto Oswaldo Cruz-Fiocruz, Av. Brasil 4365, 21045-900 Rio de Janeiro, RJ, Brazil **Hospital Municipal Salles Netto, Rio de Janeiro, RJ, Brasil ***Hospital Municipal Souza Aguiar, Rio de Janeiro, RJ, Brasil

Rotavirus is a major cause of infantile acute diarrhea, causing about 440,000 deaths per year, mainly in developing countries. The World Health Organization has been recommending the assessment of rotavirus burden and strain characterization as part of the strategies of immunization programs against this pathogen. In this context, a prospective study was made on a sample of 134 children with acute diarrhea and severe dehydration admitted to venous fluid therapy in two state hospitals in Rio de Janeiro, Brazil, from February to September 2004. Rotavirus where detected by polyacrylamide gel electrophoresis (PAGE) and by an enzyme-linked immunoassay to rotavirus and adenovirus (EIARA) in $48 \%$ of the children. Positive samples for group A rotavirus $(n=65)$ were analyzed by reverse transcription/heminested multiplex polymerase chain reaction to determine the frequency of $G$ and $[P]$ genotypes and, from these, 64 samples could be typed. The most frequent G genotype was G1 (58\%) followed by G9 $(40 \%)$. One mixed infection $(G 1 / G 9)$ was detected. The only [P] genotype identified was P[8]. In order to estimate the rotavirus infection frequency in children who acquired diarrhea as hospital infection in those hospitals, we studied 24 patients, detecting the pathogen in $41 \%$ of them. This data suggest that genotype G9 is an important genotype in Rio de Janeiro, with implications to the future strategies of vaccination against rotavirus, reinforcing the need of continuous monitoring of circulating strains of the pathogen, in a surveillance context.
\end{abstract}

Key words: gastroenteritis - hospitalization - rotavirus A - genotypes - Rio de Janeiro - Brazil

Group A rotaviruses are the major cause of severe diarrhea in children, leading to about 440,000 deaths per year, the majority in the developing world (Parashar et al. 2003). World Health Organization has been recommending local surveys to assess rotavirus burden and the characterization of circulating strains as part of strategies on implementing vaccination programs against this pathogen (Hoshino \& Kapikian 2000). The development of mono and polyvalent vaccines (Kapikian et al. 1996, Clark et al. 2004) reinforced the need of molecular characterization of group A rotaviruses in several regions of the world (Santos $\&$ Hoshino 2005). An increasing frequency of the emerging genotype G9 has been observed in various countries (Armah et al. 2003, Kirkwood et al. 2003, van der Donck et al. 2003, Zhou et al. 2003, Arista et al. 2004, Sung et al. 2004, Urbina et al. 2004, Jiraphongsa et al. 2005, Chen et al. 2005, Kebaabetswe et al. 2005). In Brazil, two studies conducted in Rio de Janeiro with fecal samples collected in the late 1990s identified frequencies of G9 of 13 and $15.3 \%$ (Araujo et al. 2001, Santos et al. 2001). In Goiânia (Central Western region of Brazil), the frequency of detection of G9 strains reached $34.4 \%$ (Costa et al. 2004). Recently,

Financial support: IOC-Fiocruz/MS, CNPq, CGLAB/SVS/MS ${ }^{+}$Corresponding author: jpgleite@ioc.fiocruz.br

Received 12 December 2005

Accepted 22 March 2006
Santos et al. (2005) described the predominance of rotavirus genotype G9 in Salvador, BA. The objective of the present study was to detect $G$ and $[P]$ genotypes of group A rotaviruses from children admitted with gastroenteritis and severe dehydration requiring intravenous fluid therapy in two state hospitals in Rio de Janeiro, Brazil.

\section{CASUISTICS AND METHODS}

Study population and collection of clinical specimens - From February to September 2004, 134 fecal samples were collected from the same number of patients up to 8 years of age presenting acute gastroenteritis and severe dehydration, admitted to venous fluid therapy in two public hospitals in Rio de Janeiro, Brazil. From these, 75 patients were admitted at Souza Aguiar Hospital, a large state emergency hospital, and 59 were admitted at Salles Netto Hospital, a small public pediatric hospital. Both unities are situated in the same region, downtown in Rio de Janeiro, and attend people of low socioeconomic level living in urban areas. The mean age of the patiens was 14,7 months and was higher in Souza Aguiar (17,3 months) than in Salles Netto (11,3 months). In the same period, 24 patients (10 in Souza Aguiar, 14 in Salles Netto) who acquired diarrhea while admitted in both hospitals with other conditions (mainly respiratory tract infections) where studied to assess the frequency of rotavirus infection.

Fecal samples were collected from the subjects after written consent given by their parents, when a clinical and epidemiological questionnaire was filled. This study 
was approved by the Ethics Committee on Research of the Evandro Chagas Research Institute of the Oswaldo Cruz Foundation. Data were processed on EpiInfo version 3.2 and presented like descriptive statistics of the whole sample and stratified by age. Comparison of frequencies between different age groups was performed by chi-square test.

Rotavirus detection and genotype characterization Polyacrylamide gel electrophoresis (Pereira et al. 1983) and a combined enzyme immunoassay for rotavirus and adenovirus (EIARA) (Pereira et al. 1985) were used to detect group A rotavirus in 10\% fecal suspensions in phosphatebuffered saline (PBS) pH 7.4.

For $\mathrm{G}$ and $\mathrm{P}$ genotyping, the viral dsRNA was extracted from rotavirus positive clarified stool supernatants by the glass powder method (Boom et al. 1990). The dsRNA was reverse transcribed (RT) and amplified by PCR using a pair of consensus primers corresponding to a conserved nucleotide sequence of the VP7 (Gouvea et al. 1990, Das et al. 1994) or VP4 (Gentsch et al. 1992) genes. The cDNA fragment amplified of $904 \mathrm{bp}$ (VP7) or $876 \mathrm{bp}$ (VP4) was then used as a template to a second PCR, carried out by using $1 \mu \mathrm{l}$ of the first amplicon and a pool of genotype- specific primers complementary to variable regions of the VP7 (Gouvea et al. 1990) or VP4 (Gentsch et al. 1992) gene. Temperature and time conditions for PCR amplifications were performed as originally described (Gouvea et al. 1990, Gentsch et al. 1992). Distilled Milli-Q water was used as a negative control in all steps, and recommended manipulations for PCR procedures were carried out as a precaution to avoid false-positive results.

\section{RESULTS}

Frequency of rotavirus detection in the sample was $48 \%$, being higher in Salles Netto than in Souza Aguiar Hospital (59 and $40 \%$ respectively). Stratifying sample by age, frequency of rotavirus infection was higher in the group with 7 to 12 months (59\%), as showed in Table I. G1 and G9 were the only detected genotypes (57 and 40\% respectively). One sample was characterized as a mixed infection (G1/G9) and one sample could not be typed. All specimens were characterized as P [8]. Age distribution of characterized genotypes is shown in Table I. Among 24 children with nosocomially acquired diarrhea, 10 (41\%) had rotavirus detected in fecal samples. Five samples where characterized as G1, four as G9 and one could not be typed, as presented in Table II.

TABLE I

Frequency of rotavirus detection and G genotype characterization in 134 children with gastroenteritis and dehydration admitted at two hospitals in Rio de Janeiro, from February to September, 2004

\begin{tabular}{|c|c|c|c|c|c|}
\hline \multirow[b]{2}{*}{$\begin{array}{l}\text { Age group } \\
\text { (months) }\end{array}$} & \multirow[b]{2}{*}{$\mathrm{N}$} & \multirow[b]{2}{*}{$\begin{array}{c}\text { Rotavirus positive } \\
\mathrm{N}(\%)\end{array}$} & \multicolumn{3}{|c|}{ G genotype } \\
\hline & & & $\begin{array}{c}\mathrm{G} 1 \\
\mathrm{~N}(\%) \\
\end{array}$ & $\begin{array}{c}\text { G9 } \\
\mathrm{N}(\%)\end{array}$ & $\begin{array}{c}\mathrm{G} 1+\mathrm{G} 9 \\
\mathrm{~N}(\%) \\
\end{array}$ \\
\hline$<=12$ & 71 & $42(59)^{a}$ & $27(64)$ & $14(34)$ & $1(2,4)$ \\
\hline 13 to 48 & 44 & $15(34)^{a}$ & $8(53)$ & $7(46)$ & - \\
\hline$>48$ & 5 & $1(20)$ & - & $1(100)$ & - \\
\hline Not defined & 14 & $6(43)$ & $2(34)$ & $4(66)$ & - \\
\hline Total & 134 & $64(48)$ & $37(58)$ & $26(40)$ & $1(1,5)$ \\
\hline
\end{tabular}

$a$ : Odds ratio $=2,80(95 \%$ confidence interval $=1,20-6,62) \mathrm{p}<0,05$.

TABLE II

Detection and G genotype characterization of rotavirus in 24 children with nosocomially acquired diarrhea in two state hospitals in Rio de Janeiro

\begin{tabular}{|c|c|c|c|c|c|}
\hline \multirow[b]{2}{*}{ Age (months) } & \multirow[b]{2}{*}{$\mathrm{N}$} & \multirow{2}{*}{$\frac{\text { Rotavirus positive }}{\mathrm{N}(\%)}$} & \multicolumn{3}{|c|}{ G genotype } \\
\hline & & & G1 (N) & G9 (N) & Not typed \\
\hline$\leq 12$ & 14 & $7(50)$ & 3 & 3 & 1 \\
\hline$\geq 13$ & 5 & $1(25)$ & 1 & - & - \\
\hline Not defined & 5 & $2(40)$ & 1 & 1 & - \\
\hline Total & 24 & $10(42)$ & 5 & 4 & 1 \\
\hline \multicolumn{6}{|l|}{ Diagnostic on admission } \\
\hline Bronchiolitis & 16 & $7(44)$ & 4 & 3 & - \\
\hline Pneumonia & 3 & $2(67)$ & 1 & 1 & - \\
\hline Septic arthritis & 1 & - & - & - & - \\
\hline Meningitis & 1 & - & - & - & - \\
\hline Mastoiditis & 1 & - & - & - & - \\
\hline Stomatitis & 1 & $1(100)$ & - & - & 1 \\
\hline Urinary tract infection & 1 & - & - & - & - \\
\hline Total & 24 & $10(42)$ & 5 & 4 & 1 \\
\hline
\end{tabular}




\section{DISCUSSION}

New rotavirus vaccines were developed (Clark et al. 2004, De Vos et al. 2004, Salinas et al. 2005). In Brazil one of them is available in private immunization clinics since 2005 . This vaccine (Rotarix $\left.{ }^{\circledR}\right)$ was included in the governmental immunization schedule in 2006 becoming available to the whole population. The emergence of unusual rotavirus strains in developing countries is a reason for discussion about the potential efficacy of developing vaccines, as observed in the late 1990s on the occasion of the polyvalent rotavirus vaccine RRV-TV licensing in United States, when the emergent genotype G5, not included in the vaccine, was an important epidemic genotype in Brazil (Leite et al. 1996, Gouvea \& Santos 1999). Genotype G5 disappeared from the epidemiological scenario in Rio de Janeiro after 1997, followed by the emergence of genotype G9.

The data from this study reinforces the importance of this genotype, suggesting that, in the season of 2004 in Rio de Janeiro, G9 was more frequent than some classical genotypes, like G2-4, and substituted G5 as an emergent genotype, once it was detected in $40 \%$ of samples. Recently Volotão et al (2006) observed a high frequency of rotavirus genotype G9 circulating in Rio de Janeiro. These data reflect the need of continual monitoring of rotavirus genotypes circulating in the country, as part of the strategies on implementing vaccination against this pathogen. Whether new available rotavirus vaccines are effective against genotype G9, and in what extent type-specific immunity play a role in this efficacy is still under discussion. Continuous rotavirus surveillance, including monitoring of vaccinated children will be important on elucidating such questions.

Also, rotavirus seems to be an important pathogen in nosocomially acquired diarrhea, infecting infants admitted mainly with respiratory tract infections, like bronchiolitis. The coincidental peak of activity of rotavirus and syncytial respiratory virus (Thuret et al. 2004), the drier and colder months, can predispose infants to acquire gastroenteritis in the hospital setting, prolonging hospitalization periods. Fischer et al. (2004) estimates that in the United States alone, as many as $25 \%$ of rotavirus hospitalizations or approximately 16,000-18,000 hospitalizations each year might be due to rotavirus infections acquired within hospitals. Le Roux et al. (2004) shown that in a French pediatric setting $16 \%$ of infants with bronchiolitis have developed nosocomial intestinal infections.

In this context an effective vaccine could prevent the hospital acquisition of rotavirus infection; which in some pediatric settings is a very common event.

\section{ACKNOWLEDGMENTS}

To Dr Marize Pereira Miagostovich for helpful discussions and Gilmar Alcântara de Mattos for technical assistance.

\section{REFERENCES}

Araujo IT, Ferreira MS, Fialho AM, Assis RM, Cruz CM, Rocha M, Leite JP 2001. Rotavirus genotypes P[4]G9, $\mathrm{P}[6] \mathrm{G} 9$, and P[8]G9 in hospitalized children with acute gastroenteritis in Rio de Janeiro, Brazil. J Clin Microbiol 39: 1999-2001.

Arista S, Giammanco GM, De Grazia S, Migliore MC, Martella
V, Cascio A 2004. Molecular characterization of the genotype G9 human rotavirus strains recovered in Palermo, Italy, during the winter of 1999-2000. Epidemiol Infect 132: 343349.

Armah GE, Steele AD, Binka FN, Esona MD, Asmah RH, Anto F, Brown D, Green J, Cutts F, Hall A 2003. Changing patterns of rotavirus genotypes in Ghana: emergence of human rotavirus G9 as a major cause of diarrhea in children. Clin Microbiol 41: 2317-2322.

Boom R, Sol CJA, Salimans MMM, Jansen CL, Wertheim-van Dillen PME, Van der Noordaa J 1990. Rapid and simple method for purification of nucleic acids. J Clin Microbiol 28: 495-503.

Chen KT, Chen PY, Tang RB, Huang YF, Lee PI, Yang JY, Chen HY, Bresee J, Hummelman E, Glass R 2005. Sentinel hospital surveillance for rotavirus diarrhea in Taiwan, 2001-2003. J Infect Dis 192 (Suppl.): 44-48.

Clark HF, Bernstein DI, Dennehy PH, Offit P, Pichichero M, Treanor J, Ward RL, Krah DL, Shaw A, Dallas MJ, Laura D, Eiden JJ, Ivanoff N, Kaplan KM, Heaton P 2004. Safety, efficacy, and immunogenicity of a live, quadrivalent human-bovine reassortant rotavirus vaccine in healthy infants. J Pediatr 144: 184-190.

Costa PS, Cardoso DD, Grisi SJ, Silva PA, Fiaccadori F, Souza MB, Santos RA 2004. Rotavirus A infections and reinfections: genotyping and vaccine implications. J Pediatr (Rio J) 80: 119-122.

Das BK, Gentsch JR, Cicirello HG, Woods PA, Gupta A, Ramachandran M, Kumar R, Bhan MK, Glass RI 1994. Characterization of rotavirus strains from newborns in New Delhi, India. J Clin Microbiol 32: 1820-1822.

De Vos B, Vesikari T, Linhares AC, Salinas B, Perez-Schael I, Ruiz-Palacios GM, Guerrero Mde L, Phua KB, Delem A, Hardt K 2004. A rotavirus vaccine for prophylaxis of infants against rotavirus gastroenteritis. Pediatr Infect Dis $J$ 23(Suppl.): 179-182.

Fischer TK, Bresee JS, Glass RI 2004. Rotavirus vaccines and the prevention of hospital-acquired diarrhea in children. Vaccine 22 (Suppl.): 49-54.

Gentsch JR, Glass RI, Woods P, Gouvea V, Gorziglia M, Flores J, Das BK, Bhan MK 1992. Identification of group A rotavirus gene 4 types by polymerase chain reaction. J Clin Microbiol 30: 1365-1373.

Gouvea V, Glass RI, Woods P, Taniguchi K, Clark HF, Forrester B, Fang ZY 1990. Polymerase chain reaction amplification and typing of rotavirus nucleic acid from stool specimens. J Clin Microbiol 28: 276-282.

Gouvea V, Santos N 1999. Rotavirus serotype G5: an emerging cause of epidemic childhood diarrhea. Vaccine 17: 12911292.

Hoshino Y, Kapikian AZ 2000. Rotavirus serotypes: classification and importance in rotavirus epidemiology, immunity and vaccine development. J Health Popul Nutr 18: 5-14.

Jiraphongsa C, Bresee JS, Pongsuwanna Y, Kluabwang P, Poonawagul U, Arporntip P, Kanoksil M, Premsri N, Intusoma U, Rotavirus Surveillance Project Thailand Study Group 2005. Epidemiology and burden of rotavirus diarrhea in Thailand: results of sentinel surveillance. J Infect Dis 192 (Suppl.): 87-93. 
Kapikian AZ, Hoshino Y, Chanock RM, Perez-Schael I 1996. Efficacy of a quadrivalent rhesus rotavirus-based human rotavirus vaccine aimed at preventing severe rotavirus diarrhea in infants and young children. J Infect Dis 174 (Suppl.): 65-72.

Kebaabetswe LP, Sebunya TK, Matsheka MI, Ndung'u T 2005. Detection and molecular characterization of group a rotavirus from children in northern Botswana. East Afr Med J 82: 203-208.

Kirkwood CD, Bogdanovic-Sakran N, Clark R, Bishop RF, Graeme LB 2003. Report of the Australian Rotavirus Surveillance Program, 2002/2003. Commun Dis Intell 27: 492495 .

Leite JPG, Alfieri AA, Woods PA, Glass RI, Gentsch JR 1996. Rotavirus $\mathrm{G}$ and $\mathrm{P}$ types circulating in Brazil: characterization by RT-PCR, probe hybridization, and sequence analysis. Arch Virol 141: 2365-2374.

Le Roux P, Marshall B, Toutain F, Mary JF, Pinon G, Briquet E, Le Luyer B 2004. Nosocomial viral infections in a pediatric service: example of rotaviral gastroenteritis and respiratory syncytial viral bronchiolitis. Arch Pediatr 11: 908915.

Parashar UD, Hummelman EG, Bresee JS, Miller MA, Glass RI 2003. Global illness and deaths caused by rotavirus disease in children. Emerg Infect Dis 9: 565-572

Pereira HG, Azeredo RS, Leite JPG, Candeias JA, Rácz ML, Linhares AC, Gabbay YB, Trabulsi JR 1983. Electrophoretic study of the genome of human rotaviruses from Rio de Janeiro, São Paulo and Pará, Brazil. J Hyg (Cambr) 90: 117125 .

Pereira HG, Azeredo RS, Leite JPG, Andrade ZP, Castro L 1985. A combined enzyme immunoassay for rotavirus and adenovirus (EIARA). J Virol Methods 10: 21-28.

Salinas B, Schael IP, Linhares AC, Ruiz Palacios GM, Guerrero ML, Yarzabal JP, Cervantes Y, Clemens SC, Damaso S, Hardt K, De Vos B 2005. Evaluation of safety, immunogenicity and efficacy of an attenuated rotavirus vaccine, RIX4414: a randomized, placebo-controlled trial in Latin American infants. Pediatr Infect Dis J 24: 807-816.

Santos N, Volotao EM, Soares CC, Albuquerque MC, da Silva
FM, de Carvalho TR, Pereira CF, Chizhikov V, Hoshino Y 2001. Rotavirus strains bearing genotype G9 or P[9] recovered from Brazilian children with diarrhea from 1997 to 1999. J Clin Microbiol 39: 1157-1160.

Santos N, Hoshino Y 2005. Global distribution of rotavirus serotypes/genotypes and its implication for the development and implementation of an effective rotavirus vaccine. Rev Med Virol 15: 29-56.

Santos N, Volotao EM, Soares CC, Campos GS, Sardi SI, Hoshino Y 2005. Predominance of rotavirus genotype G9 during the 1999, 2000, and 2002 seasons among hospitalized children in the city of Salvador, Bahia, Brazil: implications for future vaccine strategies. J Clin Microbiol 43: 40644069.

Sung YL, Huang YF, Huang CF, Chen KT, Chen HY, Lee GH, Nong BR, Lin CS, Chuang CM, Liu FC, Chen CS, Lin CC, Hsieh KS, Liu YC 2004. Emergence of G9 serotype rotavirus as a major cause of infectious gastroenteritis in southern Taiwan. J Microbiol Immunol Infect 37: 322-326.

Thuret A, Patural H, Berthelot P, Benzait F, Martin I, Jusot JF, Teyssier G, Fabry J, Pozzetto B 2004. Prospective followup of hospital-acquired diarrhoea in 28 paediatric wards of the south-east part of France during a winter season. Pathol Biol (Paris) 52: 131-137.

Urbina D, Rodriguez JG, Arzuza O, Parra E, Young G, Castro $\mathrm{R}$, del-Portillo P 2004. G and P genotypes of rotavirus circulating among children with diarrhea in the Colombian Northern coast. Int Microbiol 7: 113-120.

van der Donck I, van Hoovels L, de Leener K, Goegebuer T, Vanderwegen L, Frans J, Rahman M, van Ranst M 2003. Severe diarrhea due to rotavirus infection in a Belgian hospital 1981-2002. Acta Clin Belg 58: 12-18.

Volotão EM, Soares CC, Maranhão AG, Rocha LN, Hoshino Y, Santos N 2006. Rotavirus surveillance in the city of Rio de Janeiro, Brazil during 2000-2004: detection of unusual strains with G8P[4] or G10P[9] specificities. J Med Virol 78: 263-278.

Zhou Y, Li L, Okitsu S, Maneekarn N, Ushijima H 2003. Distribution of human rotaviruses, especially G9 strains, in Japan from 1996 to 2000. Microbiol Immunol 47: 591-599. 